\title{
OPEN
}

\section{Author Correction: Antibiotic drug- resistance as a complex system driven by socio-economic growth and antibiotic misuse}

\author{
Bhawna Malik \& Samit Bhattacharyya \\ Correction to: Scientific Reports https://doi.org/10.1038/s41598-019-46078-y, published online 5 July 2019 \\ In the Supplementary Information file originally published with this Article, the labelling of equations, figures \\ and references in the text was omitted. These errors have been corrected in the Supplementary Information that \\ now accompanies the Article.
}

\begin{abstract}
(c) (i) Open Access This article is licensed under a Creative Commons Attribution 4.0 International License, which permits use, sharing, adaptation, distribution and reproduction in any medium or format, as long as you give appropriate credit to the original author(s) and the source, provide a link to the Creative Commons license, and indicate if changes were made. The images or other third party material in this article are included in the article's Creative Commons license, unless indicated otherwise in a credit line to the material. If material is not included in the article's Creative Commons license and your intended use is not permitted by statutory regulation or exceeds the permitted use, you will need to obtain permission directly from the copyright holder. To view a copy of this license, visit http://creativecommons.org/licenses/by/4.0/.
\end{abstract}

(c) The Author(s) 2019 